\title{
The Challenges of Competitiveness in Southeast European Countries
}

Ines Kersan-Škabić, Lela Tijanić *

Abstract:

The article examines the problem of competitiveness in Southeast European countries, with a special emphasis on the position of these countries in World Economic Forum rankings of competitiveness, as well on their potential membership in the European Union. The article determines the most problematic factors for doing business in the region. These factors represent the most important determinants of business sector competitiveness and have implications on national competitiveness. A TOWS matrix was created and established the common characteristics (strengths, weaknesses, opportunities and threats) of the countries in the region. The matrix was also used to suggest strategies for increasing competitiveness. A maxi-maxi strategy ("expansionary strategy") was suggested because it represents the best way to utilise the countries' strengths and opportunities. Cross-section analysis established that increasing gross enrolment ratio in tertiary education and direct foreign investments have the most the positive impacts on $\mathrm{GCl}$ scores.

Keywords: competitiveness, Southeast European countries, TOWS matrix, regional cooperation

JEL: F40, F43, F15, P27

DOI: $10.2478 / v 10033-009-0011-6$

\section{Introduction}

Rapid changes in Southeast European countries (SEE) which began in the $20^{\text {th }}$ century have had a significant impact on the political, economic and social situation in these countries, as well as on international relations and movements. Accession to the European Union has become the strategic aim of each country, which certainly has a large influence on the competitiveness of nonmember countries. In the EU accession process, and especially after EU accession (Bulgaria, Romania and Greece), the problem of competitiveness for Southeast European countries becomes more obvious. This problem has been intensified by the globalisation process, which has imposed new challenges on SEE.

The common features of these countries are low competitiveness and extremely slow reform processes, which are necessary for improving the situation in the region. The region's countries (aside from Greece) have only started to establish institutional relations with the EU in the last decade. These relations above all involve trade, but also include the possibility for these countries to gradually integrate into EU structures. However, this group of countries is different from developed West European countries in terms of their political and economic features. The region is characterized by its recent wars and ethnic conflicts, deficient democracies and the lack of political pluralism. Not enough attention is paid to the imperative of respecting human rights and

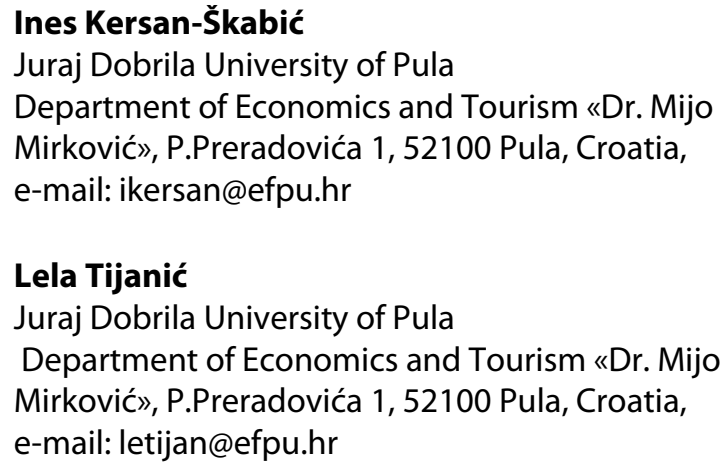


those of national minorities. On the other hand, this region is economically underdeveloped when compared to the EU, leaving open the possibility that the EU integration process could bring many negative effects because of the insufficient development of competitiveness in these markets, which in turn could lead to ineffective production. Because of this situation, these countries have reached a turning point in their development, and must use their advantages in order to survive and prosper in today's increasingly competitive global markets.

The aim of this research is to investigate the factors of SEE competitiveness, and to analyse their underdeveloped areas in order to suggest optimal measures for improving their position on the European and world markets.

Previous studies of the competitiveness of SEE are rare and usually deal with specific aspects of competitiveness. This research goes one step further by offering a complex approach to the analysis of competitiveness. It analyses current indicators of SEE's competitiveness according to the Global Competitiveness Report and Lisbon Agenda goals (regarding the EU). A SEE TOWS matrix was made in order to propose strategies for the region. The impact of the gross enrolment ratio and FDI inflow on the countries' competitiveness is determined using multiple regression analysis.

\section{Characteristics of South East European countries $^{i}$}

The major part of the region was caught in armed and ethnic conflicts during the turbulent 1990s which resulted in numerous casualties and extensive material damage and led to the alienation and isolation of these countries. It must not be forgotten that five (or six, including Kosovo) of the countries from this region came into existence after the break-up of the ex-Yugoslavia; until the 1990s they had enjoyed good cooperation.

Since these countries, both during and after the war and ethnic conflicts, terminated their cooperation almost completely (or reduced it to a minimum) and lacked the good will and courage to rehabilitate and rebuild their relations, the international community played an important role in this respect.

\subsection{Establishment of Cooperation in the Region}

The Central European Initiative was the first attempt to establish cooperation in Central Europe. It was founded in Budapest, in 1989, when the Ministers of Foreign Affairs from Austria, Italy, ex-Yugoslavia and Hungary signed an agreement and established a common declaration of cooperation called the Quadragonal Co-operation. It gradually expanded, so that today it consists of 18 member states. In 1992 the name CEI was accepted. The main characteristic of this initiative is to encourage multilateral cooperation between its members and to intensify mutual relations with the aim of achieving higher growth, adopting European standards, as well as helping the countries in their efforts to integrate further into the European Union.

The South-East European Cooperation Process (SEECP) was launched in 1996 on Bulgaria's initiative for the purpose of strengthening regional co-operation, creating an atmosphere of trust, good neighbourly relations and stability. Its members include Albania, Bosnia and Herzegovina, Montenegro, Bulgaria, Greece, Croatia, Macedonia, Moldova, Romania, Serbia and Turkey. A special feature of SEECP is that it was launched precisely on the initiative of the countries in the region. The objectives of SEECP are as follows: strengthening the political situation and security cooperation, intensification of economic relations and co-operation in human resources, democracy and battling illegal activities. The fundamental document is the Charter on Good Neighbourly Relations, Stability, Security and Cooperation in South Eastern Europe which was signed at the meeting of these countries' presidents and governments in Bucharest on February 12, 2000.

In 2006, the EU accepted the Southeast European Cooperative Initiative (SECl), which was initiated by the United States with the aim of encouraging cooperation among its participating states and facilitating their integration into European structures. The initiative included the countries of the region (Albania, Bosnia and Herzegovina, Bulgaria, Croatia, Romania, Serbia and Montenegro), as well as Hungary, Moldova, Slovenia and Turkey.

The Stability Pact for South Eastern Europe (SP) was adopted in 1999, from an EU initiative, with more than 40 partner countries and organisations included. It represents a comprehensive, long-term conflict prevention strategy based on worldwide international experience and lessons which have helped solve crises 
around the world. Conflict prevention and fostering peace can be successful only if they occur at the same time in three key sectors: the creation of a secure environment, the promotion of sustainable democratic systems and the promotion of economic and social well being. (Stability Pact. http//www.stabilitypact.org)

Since the Stability Pact was conceived as a temporary initiative lasting until February 2008, and because of the positive changes in the region's countries, the Pact was transformed. In collaboration with the European Commission, international partners and the region's countries, a plan for the Stability Pact's transformation was devised. The products of this plan were the SouthEast European Cooperation Process (SEECP), a political framework for cooperation, and the Regional Cooperation Council (RCC), whose headquarters are in Sarajevo (MVPEI 2007). The activities of the RCC will be focused on six priority areas: economic and social development; infrastructure; justice and home affairs; security cooperation; building human capital, and parliamentary cooperation.

The "New" Central European Free Trade Agreement was signed in December, 2006." This agreement was signed by Albania, Romania, Bulgaria, Croatia, Macedonia, Bosnia and Herzegovina, Montenegro, Kosovo, Moldova and Serbia. It replaces the network of 31 free trade agreements that the Southeast European countries made on a bilateral basis and foresees the formation of a free trade area until the end of 2010. According to this model, integration can contribute the most to economic cooperation among the region's countries.iii

\subsection{Economic Development}

The region's countries, although mostly developing countries (aside from Greece), differ according to their levels of economic development. Petrakos and Totev (2000) described in detail the economic development of these countries during the last decade and concluded that the whole region is confronted with unfavourable structural adaptations, as well as a tendency toward divergence rather than convergence with developed European countries. They suggest the possibility that this fragmented economic area will remain poor and on the periphery of Europe. Since then, certain improvements have been realised, but the region still remains far behind EU countries.

The indicators presented show that the largest country is Romania, and that Greece has the highest GDP per capita. There are some common characteristics among these countries' economic developments concerning certain negative trends. The unemployment rate is very high in Bosnia and Herzegovina, Macedonia and Montenegro. All the observed countries have deficits in trade balance and Montenegro, Greece and Bosnia and Herzegovina have the lowest export-to-import ratios. Croatia and Bulgaria received the highest FDI per capita but are at the same time the most indebted countries. Aside from Greece, which has for years belonged to the EU, the most developed country in SEE is Croatia.

\begin{tabular}{|l|c|c|c|c|c|c|c|c|}
\hline Countries & $\begin{array}{c}\text { Population } \\
\text { in millions }\end{array}$ & $\begin{array}{c}\text { GDP p. C. } \\
\text { at PPP (EUR) }\end{array}$ & $\begin{array}{c}\text { Unemployment } \\
\text { rate in \% }\end{array}$ & $\begin{array}{c}\text { Inflation } \\
\text { in \% } \\
\text { (CPI) }\end{array}$ & $\begin{array}{c}\text { Current } \\
\text { account } \\
\text { in \% of GDP }\end{array}$ & $\begin{array}{c}\text { Export to } \\
\text { import } \\
\text { ratio in \% }\end{array}$ & $\begin{array}{c}\text { FDI inflow } \\
\text { p.c. }\end{array}$ & $\begin{array}{c}\text { Foreign } \\
\text { debt in \% of } \\
\text { GDP }\end{array}$ \\
\hline Albania & 3.2 & 4670 & 13.6 & 2.4 & -7.6 & 27.2 & 566.3 & 20.0 \\
\hline B\&H & 3.8 & 5810 & 44.8 & 7.2 & -10.7 & 44.1 & 736.8 & 22.0 \\
\hline Bulgaria & 7.7 & 8700 & 9.0 & 7.4 & -15.7 & 68.4 & 2041.9 & 78.0 \\
\hline Croatia & 4.4 & 11730 & 11.1 & 3.2 & -7.8 & 50.2 & 4719.5 & 87.8 \\
\hline Greece & 10.7 & 22700 & 8.9 & 3.3 & $\ldots$ & 33.0 & $\ldots$ & $\ldots$ \\
\hline Macedonia & 2.0 & 6420 & 36.0 & 3.2 & -0.4 & 65.1 & 1050 & 38.1 \\
\hline Montenegro & 0.6 & 6180 & 29.6 & 3.0 & -29.4 & 36.2 & 2025 & 27.0 \\
\hline Romania & 21.6 & 8800 & 7.3 & 6.6 & -10.3 & 68.7 & 1434.7 & 30.0 \\
\hline Serbia & 10.1 & 7280 & 20.9 & 11.6 & -11.5 & 51.1 & 823.5 & 59.0 \\
\hline
\end{tabular}

Export-to-import ratio is calculated as the ratio export/import * 100 and is expressed in percentages. If the calculated value is lower than 100 , it means that the country imports more than it exports.

Table 1: Main economic indicators of SEE in 2006

Source: WIIW (2007): WIIW Handbook of Statistics 2007. Wien, AT: The Vienna Institute for International Economic Studies. 


\subsection{Relations with the $E U$}

SEE do not enjoy the same status in relation to the EU: some countries are full-members of the EU (Greece, Romania and Bulgaria), while for the others the EU established the Stabilisation and Association Process (SAA) in 1999. Among SEE, Greece was the first to become a full-member of the EU, in 1981 after the end of G. Papadopulos's dictatorship. In 1949 Greece became a member of the Council of Europe and in 1952 a member of NATO as well. But in 1967 colonel Georgios Papadopulos led a coup d'état, a military junta was established, the constitution was abolished and all political parties were banned. On behalf of the junta he controlled the overall legislative and executive authority (he also initiated a new constitution). Because of this, Greece's membership in the Council of Europe and NATO was suspended. In 1974 a referendum decided on the establishment of the current parliamentary republic and a new constitution was introduced, thus initiating the gradual democratisation of Greece and its path towards the EU. Although Greece signed the Association Agreement with the European Economic Community in 1961 (prior to the period of dictatorship), it applied for full membership in the EU only in 1975. The European Commission expressed a negative opinion, that is, a recommendation that before its final integration into the EU, Greece had to implement a transitional pre-accession period because of its economic problems at the time. Nevertheless, due to political reasons, the European Council rejected the opinion of the European Commission, so that membership negotiations started in July 1976 and Greece became a full-member of the EU in 1981.

The EU launched the Stabilisation and Association Process, which has been an effective framework for political dialogue, trade development between the EU and SEE, as well as a particular help for the Western Balkans. A new type of contract which the EU set up for countries included in this process was set out as its most important element - the Stabilisation and Association Agreements (SAA) that EU signed with all of the region's countries, aside from Kosovo. It is interesting that EU signed this agreement with Serbia at the end of April 2008, even though Serbia did not prove its cooperation with the International Crime Tribunal for the former Yugoslavia at the Hague, which the EU insisted on during negotiations for signing the SAA with Croatia. Because the Netherlands and Belgium were opposed, the SAA ratification will start and the Interim Agreement will come into force only after Serbia realizes full cooperation with the ICTY. Regardless, this approach to the signing of the SAA with Serbia represented an exception in the EU's policy toward SEE.

\section{Competitiveness of southeast european countries}

Today, competitiveness is the key point of interest among both developed and developing countries. Developed countries, for example EU countries, try to find measures and ways to increase their competitiveness, welfare and prestige on the world market. On the other hand, developing countries fight against high and often increasing trade deficits which are the result of both growing consumption and the banks' credit activity, which leads to higher foreign indebtedness.

Although competitiveness represents an important and pressing problem regarding the economic prosperity of each country, research on the determinants of SEE competitiveness are rare and, usually focus just on one country. Ickis (2006) studies the effect of competitiveness councils on the microeconomic business environment, analysing the role of these councils using the examples of Ireland, Croatia and five countries in Central America. He points out the importance for the business sector to take over the responsibility for competitiveness, while the government has to play its role in stimulating a friendlier environment for entrepreneurial development. Weihrich (1999) analyses Germany's competitiveness by using the TOWS matrix approach, which renders a nation's business activities more feasible and efficient within the international arena through proper identification and optimal utilization of each country's factor endowments, thereby promoting the nation's continued global success. Ouardighi and Somun-Kapetanovic (2007) study the differences and economic convergence of the Balkan countries, while Stančić (1998) deals with economic cooperation in Southeast Europe.

There has been no complex analysis of competitiveness in SEE. Therefore, two methods of examining competitiveness will be applied in this study: a TOWS matrix to establish the main strengths, weaknesses, threats and opportunities for competitiveness, as well as regression models in order to determine the impact of the chosen variables on competitiveness.

There are numerous determinants of competitiveness: basic requirements (institutions; infrastructure; 


\begin{tabular}{|c|c|c|c|c|c|c|c|}
\hline \multirow[b]{2}{*}{ Countries } & \multirow[b]{2}{*}{$\begin{array}{c}\mathrm{GCl} \\
\text { rank }\end{array}$} & \multicolumn{3}{|c|}{ Subindexes } & \multirow[b]{2}{*}{$\begin{array}{l}\mathrm{BCl} \\
\text { rank }\end{array}$} & \multicolumn{2}{|c|}{ Subindexes } \\
\hline & & $\begin{array}{c}\text { Basic } \\
\text { requirements }\end{array}$ & $\begin{array}{l}\text { Efficiency } \\
\text { enhancer }\end{array}$ & $\begin{array}{c}\text { Innovation and } \\
\text { sophistication } \\
\text { factors }\end{array}$ & & $\begin{array}{l}\text { Quality of the } \\
\text { national business } \\
\text { environment }\end{array}$ & $\begin{array}{c}\text { Quality operations } \\
\text { and strategy } \\
\text { ranking }\end{array}$ \\
\hline Albania & 109 & 99 & 105 & 125 & 122 & 122 & 113 \\
\hline $\mathrm{B} \& \mathrm{H}$ & 106 & 104 & 95 & 123 & 107 & 105 & 119 \\
\hline Bulgaria & 79 & 76 & 72 & 91 & 83 & 77 & 95 \\
\hline Croatia & 57 & 53 & 61 & 53 & 60 & 61 & 63 \\
\hline Greece & 65 & 48 & 57 & 59 & 53 & 52 & 57 \\
\hline Macedonia & 94 & 72 & 98 & 101 & 95 & 96 & 98 \\
\hline Montenegro & 82 & 59 & 87 & 97 & 85 & 80 & 89 \\
\hline Romania & 74 & 88 & 62 & 73 & 73 & 74 & 81 \\
\hline Serbia & 91 & 78 & 88 & 88 & 91 & 90 & 102 \\
\hline
\end{tabular}

Ranks are on a 1-to-7 scale. The higher the rank, the more competitive the country.

Table 2: The position of Southeast European Countries according to the $\mathrm{GCl} 2007-08$

Source: WEF (2008): The Global Competitiveness Report 2007-08. http://www.weforum.org (accessed May 15, 2008)

macroeconomics; health care and primary education); efficiency enhancers (higher education and training; goods market efficiency; labour market efficiency; financial market sophistication; technological readiness; market size); innovation and sophistication factors (business sophistication; innovation). (GCR, 2007-08, 4-7). Potter divided the different ways of overcoming and fulfilling the aforementioned determinants according to the following: factor-driven, efficiency-driven and innovation-driven economies. When observing SEE it can be pointed out that there are differences in terms of their belonging to a specific group:

- Albania, Bosnia and Herzegovina belong to the transition phase from stage 1 (factor-driven economies) to stage 2 (efficiency-driven economies);

- Bulgaria, Macedonia, Montenegro, Romania, Serbia belong to stage 2 (efficiency-driven economies);

- Croatia is in a transition phase from stage 2 to stage 3;

- Greece is in phase 3 (innovation-driven economy).

Factor-driven economies base their competitiveness on available factors, which usually refer to unskilled labour and natural resources; they compete with prices (as the results of the low labour force costs) and they also sell basic products. The countries in stage 2 start developing more effective production and quality products, while in stage 3 countries compete with new unique products- through innovations and the use of the most sophisticated processes of production (wages and standards of living are high). Among SEE, only Greece is in the $3^{\text {rd }}$ stage; Croatia is approaching this stage, but most of the countries are in stage 2 .
The World Economic Forum measures the competitiveness of nations and issues the annual Global Competitiveness Report. Countries are ranked according to two key indexes: $\mathrm{GCl}$ (Global Competitiveness Index), which takes into account the microeconomic and macroeconomic foundations of national competitiveness: the quality of the macroeconomic environment, development of public institutions and technological achievements, and the $\mathrm{BCl}$ (Business Competitiveness Index) which refers to strategies and economic policies supportive of high current levels of productivity and also measures the quality of the microeconomic environment in which the companies compete. The $\mathrm{GCl}$ for 2007-08 comprised 131 countries, and the $\mathrm{BCl} 127$ countries. ${ }^{\text {iv }}$

According to the $\mathrm{GCl}$, Croatia has the best total rank and, at the same time, the best individual ranks. The biggest difference between Croatia and the other observed countries are innovation and sophistication factors, where Croatia ranks $53^{\text {rd }}$ with a score of 3.8 , while most of the countries are ranked below $70^{\text {th }}$. Bosnia and Herzegovina and Albania have the worst results and rank $106^{\text {th }}$ and $109^{\text {th }}$ respectively. The reasons for this are their low scores concerning innovation and sophistication factors, institutions, infrastructures and market efficiency. According to the $\mathrm{BCl}$, the highest ranked country is Greece, which has the highest scores in terms of quality of national business environment and quality of operations and strategy. Croatia is in $2^{\text {nd }}$ place, while the lowest ranked are again Albania and Bosnia and Herzegovina. 


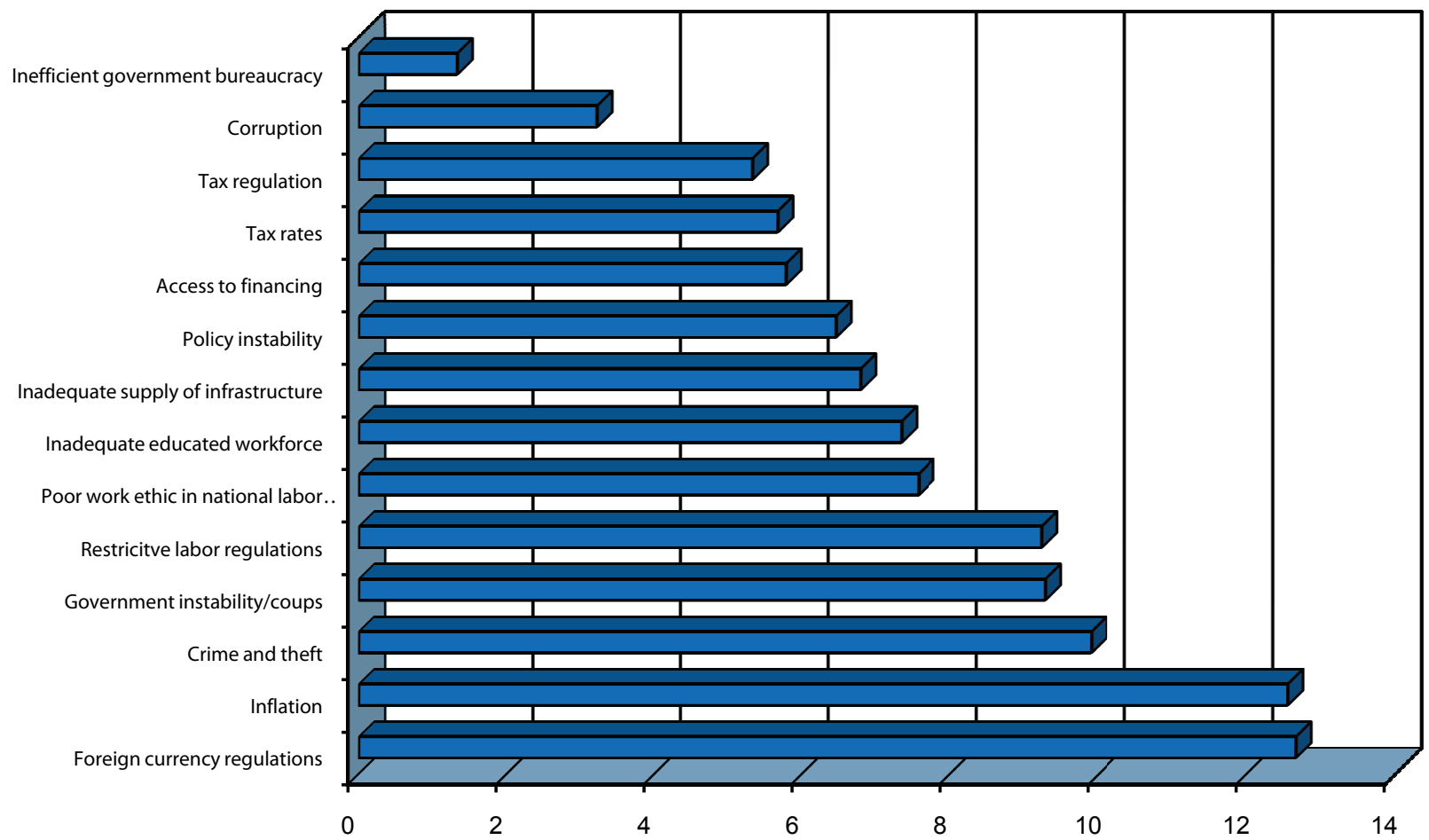

Ranks were calculated by adding up the individual ranks of the problematic areas in the countries examined (according to business executives' responses), so that the lowest rank represents the most problematic area (the one most of the respondents rank as the most problematic), and the highest rank represents the least problematic area.

Figure 1: The most problematic factors for doing business in Southeast European Countries

Source: authors' calculation, according to the WEF (2008): The Global Competitiveness Report 2007-2008

According to the questionnaires addressed to business executives (GCR part), the 5 most problematic factors in doing business are the following: inefficient government bureaucracy; corruption; tax regulations; tax rates and access to financing.

Besides the WEF rankings of competitiveness, it would be interesting to analyse these countries' levels of progress according to the Lisbon Agenda goals (which regard EU membership). The World Economic Forum analysed the progress among EU member states and potential candidate countries according to the Lisbon strategy goals. It measured eight separate dimensions which comprise critical areas of competitiveness: creating an open and competitive information society for everyone, development of the economy based on innovations, research and development; liberalisation (setting up a Single European Market, state aid and competition policy); industry development networks in telecommunications, utility services and transport; creating effective and integrated financial services; improvements in the business environment (start-up and legislative framework); incremental social inclusion. (involving people in the work force, additional qualifications and modernising social protection; enhancement (assurance) for sustainable development. (WEF 2006))

The table shows that Greece, although ranked lower than Croatia (according to the GCR), here still holds the $1^{\text {st }}$ position as well as having the best scores in all subindexes. The only exception is for the sub-index regarding the Information Society, where Croatia achieved better results. This is the result of a higher level of development in that country's competitiveness strategy, which Greece still has to work on as an EU member. Considering there are 25 member states of the EU, the position of Greece is poor, ranking $23^{\text {rd }}$ (running behind Italy, Poland, and now Romania and Bulgaria). More detailed analyses show that these countries lag behind mostly in the following subindexes: Information Society, Sustainable Development and Social Inclusion. They lag behind the least in Network Industries. This indicates the need for a more systematic approach toward the problem of competitiveness and, at the same time, for the countries to be active in different areas. 


\begin{tabular}{|c|c|c|c|c|c|c|c|c|c|c|}
\hline \multirow[b]{2}{*}{ Countries } & \multicolumn{2}{|c|}{ Final Index } & \multicolumn{8}{|c|}{ Subindexes } \\
\hline & $\begin{array}{l}\underset{c}{c} \\
\stackrel{\mathbb{D}}{\simeq}\end{array}$ & ڤัँ & 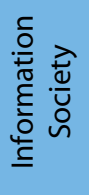 & 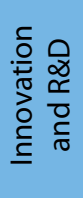 & 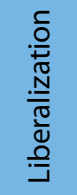 & 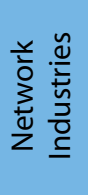 & 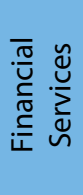 & 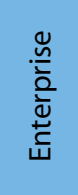 & 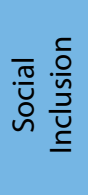 & 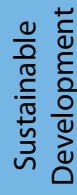 \\
\hline Greece & 1 & 4.19 & 3.17 & 3.77 & 4.32 & 5.09 & 5.27 & 4.14 & 3.79 & 3.98 \\
\hline Croatia & 2 & 3.93 & 3.69 & 3.32 & 4.07 & 4.65 & 4.53 & 3.81 & 3.40 & 3.96 \\
\hline Romania & 4 & 3.59 & 3.21 & 3.17 & 3.89 & 3.51 & 4.19 & 3.91 & 3.62 & 3.33 \\
\hline Bulgaria & 5 & 3.31 & 3.09 & 2.92 & 3.49 & 3.86 & 3.80 & 3.43 & 2.87 & 3.00 \\
\hline Macedonia, FYR & 6 & 3.28 & 2.51 & 2.79 & 3.56 & 3.71 & 3.98 & 3.51 & 3.17 & 3.04 \\
\hline Serbia and Montenegro & 7 & 3.14 & 2.80 & 2.94 & 3.50 & 3.39 & 3.77 & 3.32 & 2.80 & 2.59 \\
\hline EU25 average & & 4.84 & 4.58 & 4.24 & 4.92 & 5.36 & 5.60 & 4.59 & 4.40 & 5.05 \\
\hline
\end{tabular}

Ranks are on a 1-to-7 scale. The higher the rank, the more competitive the country.

Table 3: Rankings and Scores of Southeast European Countries

Source: WEF (2007): The Global Competitiveness Report 2006-2007. http://www.weforum.org (accessed May 15, 2008)

\section{National Framework for Increasing Competitiveness}

The perceived need for increasing competitiveness indicates that it is necessary for the countries to have a strategy of economic development and to act in a direction that will realise certain goals of competitiveness, through different activities, subjects and institutions. Special bodies play important roles as well. For example, the National Competitiveness Council in Ireland explores the country's existing situation, including the weaknesses and strengths of Ireland's competitive position, as well as determining the challenges of competitiveness which Ireland's economy will have to face and deal with in the future.

The National Competitiveness Council in Croatia was founded according to Ireland's example in 2002. The members of the Council come from different groups: government officials, economic experts, union officials, scientists and academics. The aim of this Council is to promote and stimulate competitiveness and the productivity of the Croatian economy in the long run (which will finally result in a continuous sustainable growth of the standard of living and a better quality of life). The Council publishes the Annual Report on Croatian Competitiveness every two years, and issued "55 Policy Recommendations for Raising Croatia's Competitiveness" in 2004. It is currently occupied with trying to find the best way to prepare Croatia for entering the EU, as well as preparing Croatia to become a member of the group of the 40 most competitive countries in the world.
Macedonia has had its National Entrepreneurship and Competitiveness Council since 2003. It was founded with the aim of improving the business environment of Macedonia, as well as increasing its international competitiveness. The challenges it faces include increasing employment, attracting investments, improving infrastructure, preparing for EU accession, implementing the rules of the WTO and increasing the standard of living. Albania, Bosnia and Herzegovina, Serbia and Montenegro have neither national competitiveness councils nor integral strategies for increasing their economies' competitiveness. Their data on the competitiveness of specific activities are segmented and often only certain sectors are pointed out. The USAID (United States Agency for International Development) plays an important role through its Economic Growth Programme (in Albania and Bosnia and Herzegovina), the purpose of which is to improve economic policy and the business environment, increase the competitiveness of the private sector, strengthen the financial services sector and improve access to finance, as well as developing and improving access to economic and social infrastructure.

According to the revised Lisbon Strategy, Greece, Romania and Bulgaria are obliged to introduce National Reform Programmes as strategies for increasing the national competitiveness. Greece introduced this programme in 2005, Romania and Bulgaria in 2006. These programmes define the priorities, aims as well as activities that need to be carried out in order to achieve 


\section{INTERNAL ENVIRONMENT}

\section{STRENGTHS (S)}

$\square$ availability of natural resources, diverse countryside, cultivated land, fruitful areas for different products and cultivation, water wealth

$\square$ favourable transport position (connection between Europe and Middle East)

$\square \quad$ closeness of developed EU countries

$\square \quad$ tourism and developed plans for better positioning

large markets

reform implementation within the context of EU accession

high rates of economic growth

promoting the development of small and medium enterprises

$\square$ FDI inflow

$\square \quad$ well educated labour force

$\square$ the Bologna process implementation in the system of higher education

$\square$ promoting innovations, orientation on science, research and development

\section{WEAKNESSES (W)}

$\square \quad$ unused natural resources

$\square$ problems in agriculture: abandoned rural areas, insufficient capital for agriculture infrastructure development

$\square$ decreasing trend of energy intensity, high energy import dependence

$\square \quad$ unrecognised products and services in other countries (EU)

$\square \quad$ big gap between the development levels of the countries (and between various regions inside countries)

$\square \quad$ areas with development problems

$\square \quad$ insufficient programmes which can help regions with development problems

$\square$ consequences of the wars, sanctions in the region

$\square$ political instability

$\square \quad$ aging population (aside from Albania)

$\square$ trade deficit

$\square \quad$ high public dept

$\square \quad$ high price of telecommunications (barrier for trade)

defects in basic institutions

non-transparent legislative

underdeveloped infrastructure

high unemployment (especially of the young labour force)

underdeveloped linkages between entrepreneurs

outstanding land ownership problems

social problems and poverty

problems with national minorities

corruption

crime

underground economy

$\square$ low technological

sophistication

$\square$ brain drain

$\square \quad$ inadequate protection of intellectual property

the Lisbon goals. The implementation of the programmes is monitored through annual Implementation Reports which point out the achieved results, and which have a

\section{EXTERNAL ENVIRONMENT}

\section{OPPORTUNITIES (O)}

benefits of the EU accession

international peace and stability initiatives

SAA

participation in international trade flows

regional trade agreements and agreements with other countries

$\square \quad$ expanding into the markets outside the EU

$\square$ reduction of the market segmentation

$\square$ mutual cooperation and helping countries in the region

$\square$ development programmes to reduce the gap between

the development levels of the various regions and to reduce poverty

$\square$ active cooperation with international institutes

help from World Bank, EBRD, EIB

EU funds financing

\section{THREATS (T)}

relationship with the EU and potential membership cost of the EU accession

口 political instability- relations in Kosovo, threats for the whole region

- regional conflicts (Kosovo, Albania- Serbia, Serbia- B\&H, Greece- Macedonia...)

$\square \quad$ Middle East conflicts- war in Iraq

risk of terrorist attacks

$\square$ competitiveness of other EU countries, USA and Japan

$\square$ pressure of foreign private companies on domestic companies

$\square$ ecological and other EU constraints

Table 4: TOWS Matrix- Southeast European Countries

Source: authors' research

positive effect by stimulating the countries to develop continuously. In general, only a few countries have developed an integrated approach for solving the problems of competitiveness, while the remainder have neither the integral policy nor the institutions to monitor them.

\section{Challenges facing competitiveness in Southeast Europe}

\subsection{TOWS Matrix of National Competitiveness}

When developing the national strategies that small countries need to be able to survive competition on the global market, different analyses from the field of strategic management can be carried out, such as the TOWS matrix. This approach supplements Porter's analysis of comparative advantages (Wiehrich 1999). 


\section{S-O strategy: Maxi- maxi \\ Using strengths to take advantage of opportunities}

$\square$ using natural resources for development of products which will compete in the international trade market and with other EU countries

$\square$ utilising the favourable geographic location for the exchange of goods and for travellers

$\square$ further development of tourism will bring the possibility for SEE to compete with the most developed EU countries

$\square$ many reforms will set up stability in the region, increase cooperation between the region's countries within a wider frame

$\square$ using potential to attract direct foreign investment

$\square$ foreign investment should be directed toward production; it is necessary to invest in research and development, research institutes, development of innovation

$\square$ a skilled and low cost labour force represent an advantage for SEE

$\square$ investment in small and medium entrepreneurship can increase cooperation between countries in the region and lead to higher investments in neighbouring countries. It is necessary to promote domestic and cross-border entrepreneurial partnerships

$\square$ financial help from international institutions and also EU funds represent opportunities to maximise the countries' strengths through the realization of projects that will contribute to increasing the countries' competitiveness

\section{W-O strategy: Mini- Maxi}

Conquering weaknesses to take advantage of opportunities

$\square$ natural potential should be optimally used where there is space

$\square$ developing recognized products and services in international trade flows

$\square$ reducing the gaps between the development levels of the various regions will contribute to cohesion and expand the market of SEE

$\square$ stabilising the political situation and conflicts in the region is essential for international trade flows and cooperation with the EU

$\square$ increasing the macroeconomic stability in the region's countries in order to compete with other EU countries

$\square$ reforming basic institutions and initiating the reconstruction and modernisation of the infrastructure, all with international contributions

$\square$ highlighting social problems that are barriers to establishing peace and stability

$\square$ addressing the problem of refugees, particularly because their number has increased because conflicts in the region

$\square$ special emphasis should be given on measures to combat corruption and crime

$\square$ educated experts should be employed and rewarded to prevent their emigration (brain drain)

$\square$ promoting innovation, research and development of technology

\section{S-T strategy: Maxi- Mini}

\section{Using strengths to parry or minimise threats}

$\square$ natural resources must be used in a way that successfully confronts their competitors

$\square$ favourable geographic location should be used in order to establish cooperation with Middle Eastern countries and Asia Minor, which can contribute to a decrease in the risks of conflicts among the countries in the region and also to cut down on the risks of terrorist attacks

$\square$ reforms in the context of EU accession can help achieve a stable situation in the region and to minimise conflicts among the countries

$\square$ reforms spent on time and well decrease the costs after EU accession (for non member countries) and ensure familiarity with EU restrictions

$\square$ investment in small and medium enterprises increases small countries' competitiveness

$\square$ by monitoring education processes and with more investment in research and development, countries will answer the challenges of modern changes in developed countries and become more competitive

\section{W-T strategy: Mini- mini \\ Conquering weaknesses to avoid or parry from threats}

$\square$ using natural resources and creating recognized products and services, countries can compete with the EU as well as with other competitors

$\square$ reducing the gaps between the development levels of the region and reducing the development obstacles will result in minimised social problems, contributing to stability in the region

$\square$ it is necessary to realize adequate measures to solve the many consequences of the conflicts and sanctions in the region in order to stabilise relations between the countries and to prevent further political confrontations

$\square$ reforms of basic institutions and the development of infrastructure will lead to better stability in the region and to cut the costs of entering the EU

$\square$ modernisation of the infrastructure and infrastructure interconnections will contribute to better transport linkages and enhance international trade flows

$\square$ combating crime will lead to better quality of life and region stability

$\square$ development of technological efficiency and business sophistication (investing in research and development) will increase these countries' competitive positions

$\square$ prevention of educated experts' emigration will be an answer to competition's challenges

Table 5: Strategies to increase SEE's competitiveness

Source: authors' research 
The TOWS matrix was originally introduced for analysing micro-environment levels (formulation of company strategies) but it also plays an important role on both the regional and national level. The abovementioned analysis gives a conceptual framework for developing national strategies which requires a systematic analysis of strengths and weaknesses and their integration with global opportunities and threats. These four factors are the basis for the strategy that will set out the guidelines for future development.

The TOWS matrix of SEE national competitiveness is given hereafter. Opportunities and threats represent the external environment, while the internal environment consists of strengths and weaknesses. The analysis of the countries' strengths determined the advantages by which countries can compete. Weaknesses were defined as the segments in which the countries lag behind the competition and which they can and must develop.

In creating the TOWS matrix the PEST/PESTLE analysis of environment was also used. PEST analysis describes a framework of macro- environmental factors used in external environmental scanning. Within this analysis, political, economic, social and technological, as well as legislative and environmental factors (in the PESTLE analysis) were identified. In analysing the macroenvironment, it is important to identify the factors which might in turn affect a number of vital variables that are likely to influence an organization's supply and demand levels as well as its costs. Changes that occur in society create an uncertain environment and have an impact on the country's competitiveness. The PEST/PESTLE analysis is important, especially in determining the opportunities and threats for these countries in the future. Countries must optimize their strengths and weaknesses within opportunities and threats.

The connections between external and internal factors represent the difference between the TOWS and SWOT matrices. SWOT analysis does not represent this relationship. Strengths, weaknesses, opportunities and threats were reviewed separately for Bulgaria, Romania, Albania, Bosnia and Herzegovina, Montenegro, Greece, Croatia, Kosovo, Macedonia and Serbia. Based on this, the TOWS matrix of national competitiveness was derived for the group of the Southeast European countries, which is presented in Table 4. According to this matrix, optimal strategies for further development were proposed with the aim of increasing the nations' competitiveness.

Considering the very marked weaknesses and threats of SEE countries, the mini-mini strategy would be a very good solution ("preventive strategy"). However, using this strategy, these countries' strengths, which offer the possibility for future development, would remain neglected because they would not be optimally utilized. The countries' strengths and opportunities would be optimally used with the maxi-maxi strategy ("expansionary strategy"), which is the best way to overcome weaknesses as well as to parry or avoid threats.

The SEE countries have various (natural, social...) potentials for further development that could increase competitiveness. If Southeast Europe is viewed as part of a wider Central and Eastern Europe, it can be considered a large economic market that will be attractive in the coming years. However, in order to use this large market potential effectively, it is necessary to minimize market segmentation. Small fragmented separate markets and significant differences between SEE countries in their levels of economic development additionally hinder rapid economic development. Southeast Europe still doesn't function as a unique economic complex or market, which results in the fact that other countries do not see this area as a region but as an area with many small, separate markets. Regional cooperation is one of the important elements in creating new relations in Southeast Europe characterised by political stability and economic development and represents important preconditions for the EU accession and integration.

Among SEE it is necessary to develop cooperation between the region's countries in order to compete with other larger markets. To succeed in this, the political problems and marked instability of the region should be resolved. These problems are specific to the region due to long standing conflicts which resulted in SEE lagging behind competing countries in economic development. In order to overcome these negative effects, the stability of the region should be rehabilitated and further conflicts prevented.

The transport position of the region is favourable, but the infrastructure is inadequate. Therefore, international funds could be used to solve this problem. Although they offer adequate help, the participation of international institutions should be greater. EU funding can be used (among other allocations) for the development of infrastructure as well.

The importance of the region's services sector is growing (especially in $\mathrm{B} \& \mathrm{H}$, Montenegro and Serbia, with the exception of Albania), so it is important to emphasize 
the significance of the further development of tourism in order to compete on the international market.

Reforms also should be implemented in order to remove basic obstacles for future development and increase competitiveness. So far the regional economic growth rate has not been sufficient to insure a better living standard among the population or to implement effectively necessary structural reforms (although SEE have enjoyed significant growth in the last few years). It is necessary to stimulate reforms and accelerate internal growth, and promote regional cooperation and integration in each country.

The aforementioned strategy will overcome separations between the countries as well as emphasize their advantages. Each country has to implement a strategy according to its national interests, always aiming at establishing cooperation and integration. The integration of SEE will lead to greater development.

Promoting the development of small and medium enterprises is especially significant for smaller countries like those of SEE. In this way, small and medium enterprises can compete with other companies of the region, thus exerting greater pressure on domestic companies. Entrepreneurship is a significant factor for achieving sustainable development and a higher level of competitiveness. Fostering entrepreneurship is essential for the creation of wealth and economic progress. There are some restrictions for small and medium enterprises in SEE that have to be lifted. The bureaucracies are inefficient and slow, the implementation of laws and regulations is inadequate, companies lack business cultures, corruption is widespread as well as crime, investment in research and development is insufficient, and there are a scarcity of highly qualified experts. It is important for companies to invest in research and development (which is increasingly present in SEE SMEs) in order to increase their competitiveness as well as to prevent a drain of educated experts. A significant problem in the higher education system is so-called "brain drain" from SEE, and the people who migrate from the countries are young (most of them 25-40 years old), which creates additional problems. This is especially symptomatic of Croatia, Bosnia and Herzegovina and Serbia. In the higher education system huge benefits have been obtained by implementation of the Bologna process. But it should be pointed out that in the period of adapting to this process it is important to decrease the negative effects and solve the problems of the abovementioned implementation process. A more highly educated labour force and a knowledge-based economy are imperative if these countries want to stay globally competitive and increase their standards of living. The free circulation of the labour force and capital in the whole region will contribute to SEE becoming an interesting destination for foreign investment.

\subsection{The Determinants of SEE Competitiveness- Regression Analysis}

Different determinants are taken into consideration when measuring competitiveness. Single measures are not able to capture all the elements of the concept (Buckley et al. 1988). The determinants include levels of technology (Rosenthal 1993), capital (Ray 1995), skill differences of labour (Strange 1998), entrepreneurship (Lee and Peterson 2000), factor conditions and industry competition (Porter 1990), globalization and the influence of multinationals (Krugman 1994), ideas and skills people can offer to the world economy (Reich 1997), and cultural factors (Harrison and Hunington 2000). Quantitative or qualitative competitiveness can be measured by using the IMD and WEF reports (Kovačić 2007).

Kovačić (2007) evaluates Slovenian competitiveness by quantitative and qualitative methods. He emphasises that the combination of statistical data and indicators from questionnaires is the best way to measure national competitiveness and points out that investments in technology and education represent the most important aspects for improving competitiveness.

The nine-factor model (Cho 1994; Cho and Moon 2000) comprises human variables (workers, politicians and bureaucrats, entrepreneurs, professionals) which drive the national economy forward and play an important role in explaining national competitiveness.

Ying-Chyi Chou, Ying-Ying Hsu, Hsin-Yi Yen (2008) present a model in which they measure the impact of science and technology and human resources on the national competitiveness of 42 countries, based on competitiveness indexes given in the 2006 World Competitiveness Yearbook.

Constantin and Banica (2007) propose an insight into the competitiveness of the Romanian region from a human resources perspective and identify the competitive advantages of Romania's human resources in the new context generated by its accession to the EU. They take into consideration the activity rate (active population/total population), the share of non- 
agricultural employment in total employment, the share of employment of high school, post high school and tertiary education in total employment, and the number of students enrolled in higher-education per 10,000 inhabitants.

Barro and Lee (2000), Sach and Warner (1997) show a strong positive interrelation between sustained economic competitiveness and investment in human capital.

Vukotić and Baćović (2007) emphasize the important impact of economic freedom on economic development. They present an analysis of correlation coefficients that show a strong positive interrelation between the level of economic freedom and foreign investment and conclude that the level of economic freedom is significantly correlated with all macroeconomic indicators of development. Di Rienzo, Das and Burbridge (2007) indicate that the economic freedom index is statistically significant and negatively related to countries' competitiveness and confirm that economically free countries with less institutional rigidities experience higher levels of competitiveness.

The negative impact of corruption on competitiveness is seen in different areas. Olaya (The Global Competitiveness Report 2006-2007, 2007) describes the negative impact of corruption on many of the factors enabling socio- economic development and emphasizes the significantly slow growth of corrupt countries. Institutional environments must be focused on decreasing corruption, which will have positive impacts on competitiveness.

A model representing what effects SEE competitiveness is shown below. The data were collected for the 8 countries from SEE (2006). Kosovo was treated as still a part of Serbia and Montenegro, as the analysis was conducted in 2006, before Kosovo declared its independence. Until May 2006 Serbia and Montenegro were a single country; therefore this model includes data for the two together.

A cross-section analysis was carried out. The dependent variable in the model is the $\mathrm{GCl}$ score for 2006 . $\left(\mathrm{GCl}^{v}\right)$, the independent variables being the following: gross enrolment ratio in tertiary education (EDUC ${ }^{\mathrm{vi}}$ ), FDI per capita (FDI), index of economic freedom (IEFvii), corruption perception index (CPVviii), with EU membership (EU) as a dummy variable.

The model tests the impact of the abovementioned variables on competitiveness in SEE.

After the proposed multiple linear regression the results showed a positive correlation between the $\mathrm{GCl}$ score and EDUC, FDI, IEF, while negative correlation was seen between the $\mathrm{GCl}, \mathrm{CPI}$ and $\mathrm{EU}$. These results were expected for all variables aside from EU membership (dummy variable).

The model was then tested for heteroscedasticy (Park and Breusch Pagan tests) which was confirmed to be present (the highest $t$-value was observed for the variable EDUC). The WLS method (with variable EDUC serving as the weight) was used to resolve the problem of heteroscedasticy. Afterwards a high $\mathrm{R}^{2}(0.9988)$ was noted and non-significant $p$ values $(>0,05)$ that refer to multicollinearity. Because of this, the model was tested for multicollinearity by the coefficient of correlation and the VIF test. The results showed that multicollinearity exists (given absolute values $r$ (EDUC, IEF), $r$ (EDUC, CPI), $r$ (CPI, IEF), $r$ (EDUC, EU) $>|0,8|$; VIF test $>5(n=8))$. The less significant collinear variables were dropped allowing for the final model to be arrived at (again testing for multicollinearity, with the results showing that there was none in the new model). The new model is presented in table 7.

In the model presented in table 7 , the t-values are significant $(|t|>2)$, and the $p$ values indicate that the variables are statistically significant $(p<0,05) . R^{2}$ shows 
Dependent Variable: GCI

Method: Least Squares

Sample: 18

\begin{tabular}{lrlrr}
\multicolumn{1}{c}{ Variable } & Coefficient & \multicolumn{1}{c}{ Std. Error } & t-Statistic & Prob. \\
\multicolumn{1}{c}{ C C } & 317.8222 & 10.49126 & 30.29399 & 0.0000 \\
\multicolumn{1}{c}{ FDI } & 1.287372 & 0.339660 & 3.790174 & 0.0193 \\
\hline \hline R-squared & 0.000128 & 3.62E-05 & 3.525355 & 0.0243 \\
Adjusted R-squared & 0.995801 & Mean dependent var & 10.54708 \\
S.E. of regression & 0.993701 & S.D. dependent var & 4.162219 \\
Sum squared resid & 0.330333 & Akaike info criterion & 0.920097 \\
Log likelihood & 0.436480 & Schwarz criterion & 0.896915 \\
Durbin-Watson stat & -0.220338 & F-statistic & 474.2850 \\
\hline \hline
\end{tabular}

Table 7: Regression analysis results (model without heteroscedasticy and multicollinearity) Source: authors' calculation

that the model interprets $99.58 \%$ of the variance, which means that the model is representative according to the abovementioned indicator.

The gross enrolment ratio in tertiary education is positively correlated with the countries' competitiveness, especially due to increasing awareness of the importance of education and a knowledge-based society. Foreign direct investment also has a positive impact on a country's competitiveness, but the impact is less significant.

If the gross enrolment ratio in tertiary education increases by 1 , the $\mathrm{GCl}$ score will increase by 1.29; if FDI per capita increases by 1000 , the $\mathrm{GCl}$ score will increase by 0.13 .

If the variables that were not included in the final model are regarded, the following can be concluded: the economic freedom index is correlated with foreign direct investment. Namely, if a country needs more foreign investments it is necessary to eliminate barriers for foreign capital inflow, that is, to increase the level of economic freedom and stimulate the development of institutions. The corruption perception index is also related to foreign direct investment. Corruption decreases investment in the realization of new projects, and slows growth, while large direct investments maximize opportunities for corruption. The fight against corruption can have an indirect impact on stimulating direct investments. It is also worth mentioning that the impact of EU membership changed in 2007, when two countries from SEE (Bulgaria and Romania) became EU members, which can be used as an implication for future research, keeping in mind the new countries that have appeared in the region (Kosovo and Montenegro). The dummy variable for a future study would be considerably different.
Although these countries are still developing, it should be pointed out that education is the key determinant for achieving competitiveness in developing countries as well as a very important precondition of their growth. In addition, it is necessary for these countries to further open to foreign direct investment, which can solve the problem of insufficient domestic resources for savings and investments in the economy. The aforementioned countries have problems with attracting investment because of their specific characteristics. Creating a quality education system, research centres etc. would contribute to attracting foreign direct investment which, in turn, if well managed, could increase competitiveness.

\section{Conclusion}

The processes of regional cooperation and integration have stimulated the region's countries to achieve peace and stability, as well as to create closer economic cooperation. Among their numerous common positive features, the countries' deficient competitiveness is a significant negative feature. The analyses established that Greece and Croatia are the most competitive countries according to the Global Competitiveness Index, while Greece achieved better results than Croatia in implementing the goals of the Lisbon strategy. This was expected, as Greece is an EU member country and as such has the obligation to implement a national reform program according to common directives.

Based on the individual matrix for each Southeast European country, the TOWS matrix was made for the whole SEE region and the maxi-maxi ("expansionary") strategy was proposed as the best way to utilize strengths and opportunities and overcome weaknesses. This would be the best way for the countries to successfully defend themselves from different threats or to avoid them.

If Southeast Europe is considered a part of Central and Eastern Europe, it can be established that it is a large economic market that will be attractive in the coming years. However, in order to ensure that the SEE market functions as a large market, it is necessary to reduce market segmentation. Regional cooperation is one of the 
important elements in creating new relations in SEE, which will bring political stability and economic development, which are important preconditions for the countries of this region in their EU accession processes. The most important factors for economic development will be solving the problems of corruption, increasing the efficiency of public administration and promoting entrepreneurship.. The strengths and threats of the region were analysed within the TOWS matrix and, based on the results, a cross-section analysis was used in order to establish the most important determinants of competitiveness. At first the model included the following independent variables: index of economic freedom, corruption perception index, FDI per capita, gross enrolment ratio in tertiary education and a dummy variable (EU membership). The final model indicated the strong positive impact of gross enrolment ratio in tertiary education on competitiveness, while the impact of FDI, although positive as well, was considerably lower.

The region's countries, which are rich in various resources, have a favourable transport position and are initiating reforms, have only just recently begun their transitions into market economies. In the development of their economies they have to confront numerous obstacles which they need to overcome to be able to become desirable for foreign capital as well as to improve their competitiveness. The research confirmed that knowledge (education) is the key determinant of a country's competitiveness, not only in developed countries but also in less developed ones. Therefore, the only way to increase competitiveness is to increase investments in education, modernize the programmes of higher education institutions, connect educational institutions to the economy, and increase the exchange (mobility) of teachers and students between universities, thus generating the exchange of ideas. This process will not be isolated. In the future, it will have a wide range of implications for economic development, as well as for the society as a whole. ㅁ.

\section{References}

Barro, R.J., Lee, J-W. 2000. International data on educational attainment: updates and implications. CID Working Paper 42. http://www.emeraldinsight.com/ (accessed May 14, 2008).

Bartlet, W. i Samardžija, V. 2004. The Reconstruction of Southeast Europe, the Stability Pact and the Role of the EU: An Overview. www.blackwell-synergy.com (accessed May 5, 2008).

Buckley, P.J., Pass, L.C. and Prescott, K. 1988. Measures of international competitiveness: a critical survey. Journal of Marketing Management 4 (2): 175-200.

Cho, D. S. 1994. A dynamic approach to international competitiveness: the case of Korea. J. Far Eastern Bus 1 (1): 17-36.
Cho, D.S, Moon, H.C. 2000. From Adam Smith to Michael Porter. World Scientific. http://www.emeraldinsight.com/ (accessed May 14, 2008).

Cho, D.-S., Moon, H.-C. and Kim, M.-Y. 2008. Characterizing international competitiveness in international business research: A MASI approach to national competitiveness. http://www.sciencedirect.com (accessed May 10, 2008).

Chou, Y.-C., Hsu, Y.-Y. and Yen, H.-Y. 2008. Human resources for science and technology: Analyzing competitiveness using the analytic hierarchy process. http://www.sciencedirect.com (accessed May 10, 2008).

Constantin, D.L. and Banica, G. C. 2007. Human Resources and Regional Competitiveness, The Case of Romania. $47^{\text {th }}$ Congress of the European Regional Science Association, Paris, August 29 - September 2.

Di Rienzo, C., Das, J. and Burbridge, J. 2007: Does diversity impact competitiveness? A cross country analysis. http://www.emeraldinsight.com (accessed May 15, 2008).

Dragnić, D. and Radonjić, J. 2006. Crna Gora u suvremenim FDI trendovima: Case Study: Crnogorski Telekom AD http://web.ebscohost.com/ehost (accessed May 14, 2008).

EUROSTAT 2008. Pocketbook on candidate and potential candidate countries. http://epp.eurostat.ec.europa.eu (accessed May 10, 2008).

Funke, M. i Ruhnwedel, R. 2005. Export variety and economic growth in Eastern European transition economies. http://gulliver.econ.unihamburg.de (accessed May 10, 2008).

Gillespie 2007. Foundations of Economics- Additional chapter on Business Strategy- chapter «PESTEL analysis of the macro-environment». http://www.oup.com (accessed May 11, 2008).

Gonan Božac, M. 2008. SWOT analiza i TOWS matrica- sličnosti i razlike. Ekonomska istraživanja 21 (1). http://hrcak.srce.hr (accessed May 5, 2008).

Harrison, L.E. and Hunington, S.P., eds. 2000. Culture Matters: How Values Shape Human Progress. New York, NY: Basic Books.

Ickis, J.C. 2006. Building a national competitiveness program. Journal of Business Research 59: 341-348.

Jefferson Institute 2006. Competitiveness of the Serbian Economy 2006. Belgrade, Serbia: Jefferson Institute.

Kovačić, A. 2007. Benchmarking Slovenian competitiveness by a system of indicators. http://www.emeraldinsight.com/ (accessed May $15,2008)$.

Krugman, P. 1994. Competitiveness: a dangerous obsession Foreign Affairs 73 (2): 28-44.

Lee, S.M. and Peterson, S.J. 2000. Culture, entrepreneurship orientation, and global competitiveness. Journal of World Business 35 (4): 401-16.

Lee, S. F. i Sai On Ko, A. 2000. Building a balanced scorecard with SWOT analysis and implementing "Sun Tzu's The Art of Business Management Strategies», on QFD methodology». Management Auditing Journal 15 (1,2): 68-7 6. http://www.emeraldinsight.com (accessed May 5, 2008).

Mićković, B. 2005. Globalna konkurentnost, konkurentnost Crne Goremjerenje i analiza. http://web.ebscohost.com (May 10, 2008).

Ministry of Economy and Finance- Greece 2006. National strategic reference framework. http://www.mnec.gr (accessed May 5, 2008).

Ouardighi, J.E., Somun-Kapetanovic, R. 2007. Do Balkan Countries Have a European Future? An Analysis of Real Economic Convergence, 
1989-2005. South East European Journal of Economics\& Business 2 (2): 23-30.

PESTEL analysis. http://www.improvementnetwork.gov.uk (accessed May 5, 2008).

Petrakos, G.; Totev, S. 2000. Economic Structure and Change in the Balkan Region: Implication for Integration, Transition and Economic Cooperation. International Journal of Urban and Regional Research 24: 95-113.

Porter, E.M. 1990. The Competitive Advantage of Nations, New York, NY: The Free Press.

Proctor, T. 2000. Strategic marketing management for health management: cross impact matrix and TOWS. Journal of Management in Medicine. 14 (1): 47-56. http://www.emeraldinsight.com (accessed May 15, 2008).

Ray, J.E. 1995. Managing Official Export Credits. Washington, DC: Institute for International Economics.

Reich, R. 1997. Piirideta maailm. Valmistrumine 21, sajandi kapitalismiks. London, UK: Simon \& Schuster Ltd.

Rosenthal, D. 1993. Some Conceptual Considerations on the Nature of Technological Capability Build-Up. http:// www.emeraldinsight.com/ (accessed May 15, 2008).

Rovčanin, A.; Halilbašić, M.; Tatić, K. 2008. The Role of Foreign Direct Investments in Raising National Competitiveness. Naše gospodarstvo 12: $120-128$

Sachs, J., Warner, A. 1997. Fundamental sources of long run growth. American Economic Review 87: 184-8.

The Stability Pact for South Eastern Europe. http://www.stabilitypact.org (accessed April, 20, 2008).

Stančić, M. 1998. Gospodarska suradnja zemalja Jugoistočne Europe. Slobodno poduzetništvo 8: 49-52.

Strange, S. 1998. Who are EU? Ambiguities in the concept of competitiveness. Journal of Common Market Studies. 36:101-14.

Šlaus, I. 2007. Building a knowledge-based society: The case of Southeast Europe. http://www.sciencedirect.com (accessed May 15, 2008).

The Heritage Foundation 2006. Index of Economic Freedom (2006). http://www.heritage.org/research/features/index/searchresults.cfm (accessed May 17, 2008).

Transparency International 2008. Corruption perceptions Index 2006. http://www.transparency.org/policy_research/surveys_indices/cpi/2006 (accessed May 17, 2008).

Transparency International 2008. Report on the Transparency International Global Corruption Barometer 2007. http://www.transparency.org (accessed May 17, 2008).

UNCTAD 2007. World investment report 2007.

http://www.unctad.org/en/docs/wir2007_en.pdf (accessed May 15, 2008).

UNECE 1999. Economic Survey of Europe, 2: 1-21. http://www.unece.org (accessed April, 28, 2008).

UNECE 2005. Economic Survey of Europe, 1: 45-57; 83-104. http://www.unece.org (accessed April 28, 2008).

UNESCO 2007. Education for all by 2015- Will we make it? http://unesdoc.unesco.org/images/0015/001547/154743e.pdf (accessed May 17, 2008).
UNESCO 2007. Global education digest 2007.

http://www.uis.unesco.org/template/pdf/ged/2007/EN_web2.pdf (accessed May 17, 2008).

Uvalić- Trumbić, S. 2003. Globalization and Opportunities for Development in Higher Education in Southeast Europe. http://web.ebscohost.com/ (accessed May 15, 2008).

Vukotić,V. and Baćović, M. 2006. Economic Freedom and Economic Growth in Southeast Europe. Transition Studies Review 13 (1): 81-91.

WEF 2006. The Lisbon Review 2006, Measuring Europe's Progress in Reform. http://www.weforum.org (accessed May 15, 2008).

WEF 2007. The Global Competitiveness Report 2006-2007. http://www.weforum.org (accessed May 15, 2008).

WEF 2008. The Global Competitiveness Report 2007-08. http://www.weforum.org (accessed May 15, 2008).

Weihrich, H. 1982. The TOWS Matrix- A Tool for Situational Analysis. Long Range Planning 15 (2): 54-66.

Weihrich, H. 1999. Analyzing the competitive advantages and disadvantages of Germany with the TOWS Matrix- an alternative to Porter's Model. European Business Review 99 (1): 9-22. http://www.emeraldinsight.com (accessed May 15, 2008).

WIIW 2007. WIIW Handbook of statistics 2007. Wien, AT: The Vienna Institute for International Economic Studies.

Žarić, V. 2005. Crna Gora- konkurentna destinacija za investicije (SWOT analiza). http://web.ebscohost.com (accessed May 10, 2008).

i This region includes Albania, Bosnia and Herzegovina, Bulgaria, Croatia, Macedonia, Montenegro, Romania, Serbia (plus Kosovo now) and Greece.

ii The original Agreement was signed in 1992 by the following countries: Hungary, Poland and Czechoslovakia.

iii Greece isn't a member of CEFTA, and Romania and Bulgaria ended their membership when they entered the EU.

iv Competitiveness is also monitored by The Institute for Management Development which publishes the World Competitiveness Yearbook, However most Southeast European countries aren't included in that report, so the analyses will be focused on the GCR, which produces the World Economic Forum.

${ }^{v}$ According to the The Global Competitiveness Report 2006-2007.

${ }^{v i}$ Gross enrolment ratio- total enrolment in a specific level of education, expressed as a percentage of the population.

vii Distribution of Global Economic Freedom- 0-49.9 \% repressed; 50-59.9 \% mostly not free; 60-69.9 \% moderately free; $70-79.9 \%$ mostly free; 80 $100 \%$ free.

viii CPI score- perception of the degree of corruption, ranging between 10 (highly clean) and 0 (highly corrupt). 